\title{
À Sombra de José Carlos Mariátegui: socialismo e movimentos políticos de esquerda no Peru (1960-1980)
}

Marcos Sorrilha PINHEIRO`

Resumo: O intelectual peruano José Carlos Mariátegui é uma das maiores referências político-ideológicas do socialismo latinoamericano no século $X X$ e, reconhecidamente, criador de um socialismo próprio para o continente. No entanto, ao longo das décadas de 1930 a 1950 o nome de Mariátegui esteve longe de se constituir como um referencial para a esquerda peruana. Somente a partir de 1960 foi que o nome do autor dos Siete Ensayos passou a figurar como herança reivindicada pelos partidos e movimentos políticos que compunham a Nova Esquerda Peruana naquele momento. Neste artigo apresentaremos como as idéias de Mariátegui foram retomadas e resignificadas por esses movimentos dentro de um contexto de reformulação da própria esquerda no cenário latino-americano e mundial. Em um primeiro momento apresentaremos a trajetória de surgimento e consolidação da Nova Esquerda Peruana e suas principais linhas de atuação. Em seguida, nos dedicaremos propriamente à analise do papel que as idéias de Mariátegui desempenharam para os intelectuais e partidos peruanos vinculados a esses movimentos.

Palavras-Chave: Nova Esquerda Peruana; José Carlos Mariátegui; Socialismo.

A história da esquerda peruana, entre 1930 e 1946, pode ser resumida à história do Partido Comunista. Fundado em 1928, por José Carlos Mariátegui com o nome de Partido Socialista

\footnotetext{
- Doutor em História pelo Programa de Pós Graduação em História Faculdade de História, Direito e Serviço Social - Campus de Franca 14409-160 - Franca - SP - Brasil. E-mail: jaca_rp@yahoo.com
} 
Peruano, recebeu a designação de Comunista em 1930, o que demonstrou, enfim, sua total adesão à Internacional Comunista. A mudança do nome ocorreu um mês após a morte de seu fundador e foi conduzida pelo então secretário geral do partido Eudócio Ravines.

A "bolchevização" do discurso da esquerda internacional e o culto à personalidade de Stalin garantiram a idéia de que era necessário congregar em um único partido as forças que promoveriam uma ação revolucionária no Peru. A partir de então, o PCP colocou em prática a estratégia de classe contra classe, expulsando do seu quadro de filiados os intelectuais e a pequena burguesia. Para Eudócio Ravines, o caminho para a revolução viria pelo embate entre proletários e burgueses. Por isso, até meados da década de 1940, o PCP atuou principalmente junto aos trabalhadores, adotando como estratégia a organização de greves e paralisações com objetivos insurrecionais. Ocorre que, dada a baixa industrialização do país, a fragilidade da classe operária peruana no início do século $\mathrm{XX}$ fez com que o PCP, de longe, não fosse o partido das massas no Peru. Esta função acabou sendo exercida pela APRA.

Desde o início de sua existência, a APRA se apresentou como uma alternativa ao comunismo para a revolução, uma maneira própria de se compreender o marxismo no Peru. Além disso, a figura emblemática de seu fundador, Victor Raúl Haya de La Torre, se constituiu como uma liderança a ser seguida desde os movimentos estudantis da Reforma Universitária peruana de 1919. Por conta disso, a presença avassaladora da APRA sobre as "multidões", contribuiu para que o PCP acabasse por se isolar dentro da própria sociedade.

No entanto, com a onda democrática produzida pelos anos finais da segunda guerra mundial, tanto a APRA quanto o PCP passaram a adotar uma linha mais conciliadora no debate político, que privilegiava as vias democráticas e o consenso. Isso ficou claro com a expulsão de Eudócio Ravines da direção do PCP em 1944 e a retomada da figura de Mariátegui como fundador e guia do partido. Já em 1943, apareceram as primeiras tentativas de reforçar o protagonismo de Mariátegui a frente do 
À SOMBRA DE JOSÉ CARLOS MARIÁTEGUI: SOCIALISMO...

PCP. Jorge del Prado, então secretário nacional de organização do Partido Comunista do Peru, escreveu um artigo no qual ressaltava a importância de Mariátegui como introdutor do marxismo no Peru, salientando que ele era adepto do pensamento marxista-leninista adotado pelo partido (Cf. SOBREVILLA, 2005: 48). Essa mudança de rumo do PCP provocaria sua primeira cisão. Em agosto de 1946, surgiu o Partido Obrero Revolucionario (POR) de orientação trotskista. Ainda que possuísse uma atuação tímida e de muito pouca relevância no cenário político daqueles anos, o POR representou o fim da hegemonia do PCP e o surgimento de um debate em torno da atuação da esquerda no país. Este debate se tornaria cada vez mais áspero na década seguinte.

O triunfo da Revolução Chinesa em 1949, a morte de Stalin em 1953, a discussão e questionamento do stalinismo propostos pelo comunista polonês Wladislaw Gomulka, em 1956, colocaram em cheque a hegemonia russa e abriram espaços para a reflexão do socialismo para além da via soviética. Desta forma, o socialismo deixou de ser uma experiência unicamente russa para se tornar um sistema global, que inseria novas realidades oriundas de outras partes do globo. Um exemplo claro disso, para a América Latina, foi o êxito da Revolução Cubana em janeiro de 1959.

A chegada de Fidel Castro ao poder trouxe novos ingredientes ao debate em torno dos caminhos para a revolução, como a estratégia de guerrilha, e retomou outras discussões que estavam postas de lado pelo stalinismo, como a participação dos intelectuais e dos camponeses no processo revolucionário. Assim, uma vez que a revolução como um objetivo imediato, a utilização da via armada para a tomada do poder, a possibilidade de contribuição de setores da pequena burguesia e a importância do camponês no processo de tomada do poder se tornaram perspectivas possíveis entre os cubanos, passaram a ser questionadas e absorvidas também pela esquerda peruana no final da década de 1950 e início dos 1960.

Enquanto essas transformações ocorriam no cenário político internacional, o Peru daquelas décadas também passava HISTÓRIA, São Paulo, 28 (2): 2009 
por mudanças em sua estrutura social e em sua organização política. O governo de Manuel Odría no início da década de 1950 representou um incremento na industrialização, na expansão do Estado e do setor educacional, o que levou ao surgimento de novas camadas na classe média ligadas aos setores profissionais e ao desenvolvimento da pequena burguesia local. Por outro lado, a explosão demográfica, as migrações e as revoltas camponesas demonstravam que a velha dualidade peruana (costa e serra), começava desmoronar.

Tais alterações teriam conseqüências diretas para a esquerda nacional, representadas pelo surgimento de novos organismos políticos, mas também para todos os partidos peruanos tradicionais. A APRA, por exemplo, sofreria com a reivindicação de seus setores mais radicais que criticavam o discurso conciliador de Haya de la Torre e o alinhamento às políticas democráticas norte-americanas. Além da APRA, os partidos que representavam a oligarquia, bem como o setor militar, sofreram com o mesmo problema na manutenção e formação de seus quadros. Os militares também viviam novos questionamentos ideológicos em seus quartéis por meio do pensamento progressista do CAEM (Centro de Altos Estudios Militares) e a oligarquia, por sua vez, não conseguia mais atingir a legitimidade democrática, tendo que lançar mão de constantes regimes de exceção, como foi com Sánchez Cerro e Odría. Até mesmo a intelectualidade que apoiava os setores oligárquicos tinha optado por abandonar as discussões políticas, preferindo o exílio, a vida diplomática ou a carreira universitária.

Este espaço deixado pelos partidos tradicionais foi rapidamente preenchido por movimentos progressistas nas cidades, como a Acción Popular de Fernando Belaúnde, a Democracia Cristiana dos setores católicos e o Movimiento Social Progresista que souberam representar os setores emergentes da sociedade urbana e, ao mesmo tempo, dedicar sua atenção as questões agrárias. Na serra, a lacuna foi ocupada pelos novos organismos políticos de esquerda que surgiram a partir de meados da década de 1950, entre eles o APRA Rebelde/MIR (dissidentes da APRA), a Vanguardia Revolucionaria 
À SOMBRA DE JOSÉ CARLOS MARIÁTEGUI: SOCIALISMO...

(dissidentes da AP) e o Ejército de Liberación Nacional (dissidentes do PCP). Todos, sem exceção, aderiram à via armada. Surgia então, naquele momento, a nueva izquierda peruana.

O sociólogo peruano Héctor Bejár, em seu artigo Los Orígenes de la nueva izquierda en el Perú: la izquierda guerrillera (período 1956-1967), defende a idéia de que o surgimento da nova esquerda está diretamente relacionada às questões apresentadas anteriormente. Para o autor, a data de 1956 marcou oficialmente o início da nova esquerda, por conta de ser - ano da reabertura política e da retomada da legalidade partidária, bem como do retorno de exilados e presos políticos à vida pública. No entanto, o desenvolvimento e a formação de um perfil claro da nova esquerda, bem como de suas orientações políticas somente podem ser compreendidos se levarmos em consideração quatro pontos fundamentais que, até mesmo extrapolam este ano. Seriam eles: "as transformações sociais, particularmente o movimento camponês, a revolução cubana; e no terreno político, a crise da APRA e do Partido Comunista" (BEJÁR, 1990: 354).

Segundo sua análise, a crise dos partidos tradicionais, as transformações sociais e os rumos da esquerda internacional teriam motivado o surgimento de novos organismos e lideranças de esquerda no país. No entanto, entre estes destaques, a Revolução Cubana e o caráter continental das guerrilhas latinoamericanas possuem maior ênfase em sua análise. Para Bejár, que também participou ativamente das guerrilhas da década de 1960, a guerrilha cubana trouxe à esquerda um modelo de atuação a ser seguido que possibilitava uma ruptura com as "velhas estratégias" de atuação partidária da esquerda tradicional, a negação das vias democráticas para a revolução e a inserção peruana nos movimentos guerrilheiros latinoamericanos. Esta opção, fez com que, durante a década de 1960, guerrilha e nova esquerda fossem sinônimos.

Assim como Bejár, o também sociólogo Jorge Nieto Montesinos em seu artigo com o sugestivo título ¿Vieja o nueva izquierda? concebe a importância das alterações apontadas para 
o surgimento da nova esquerda. No entanto, ao contrário de Bejár, Nieto enfatiza mais as transformações internas ocorridas no Peru. Segundo suas palavras, "existe um lento surgimento de novos sujeitos sociais. Se produz, ademais, uma crise do bloco oligárquico no poder, surgem camadas médias em conflito com a ordem oligárquica e se desenvolvem poderosas mobilizações camponesas. Guillermo Rochabrún, em um artigo publicado na revista Los caminos del laberinto, demonstrou bem como culturalmente desde de distintas perspectivas foi-se firmando do final dos anos 40 ao começo dos 50 o desenvolvimento de um novo processo de convergência intelectual. Este processo não se deu apenas com os intelectuais das universidades, que se converteu em centro de resistência, mas também nos núcleos de intelectuais ligados à APRA e ao PC e, em alguns casos, fora de ambos" (NIETO MONTESINOS, 1990: 382).

Seguindo sua análise, podemos dizer que tanto as transformações sociais e a crise dos partidos tradicionais, quanto a participação da intelectualidade nos movimentos políticos daquela época, foram fundamentais para a formação de novas opções políticas, o que resultou no aparecimento do social-progressismo e da nova esquerda.

Para Nieto, entre todas as correntes surgidas naquele momento, o social-progressismo foi aquela que teve propostas mais criativas para os dilemas da sociedade peruana, diferentemente do que se pode observar na nova esquerda. Conforme escreve Nieto, "a nova esquerda já surgiu em defasagem com esse país que começava a aparecer. Em primeiro lugar, tanto na APRA como no PC as opções surgem reclamando uma volta aos princípios primitivos de suas respectivas organizações. A nova esquerda, a chamada nova esquerda, nasce querendo ser a velha esquerda" (NIETO MONTESINOS, 1990: 383).

A adesão ao marxismo-leninismo, a retomada de velhos ícones da década de 1930, como Mariátegui e o aprismo radical de El antiinperialismo y el Apra de Haya de la Torre, e a opção armada para a revolução, somente fizeram com que a esquerda reproduzisse velhos questionamentos ${ }^{1}$. De outra maneira, a sua 
opção pela via guerrilheira, se apresentou como cópia e não como criação, reduzindo as peculiaridades dos problemas peruanos às sínteses internacionais. Segue o autor, "neste contexto, a nova esquerda se comportou segundo o velho mecanismo refletido no pensamento revolucionário. Simplificava a revolução triunfante, se imitava e se esperava que a revolução surgisse segundo uma percepção fixada nas retinas da nova esquerda" (NIETO MONTESINOS, 1990: 385).

De qualquer maneira, nova ou não, a esquerda conseguiu produzir agitações políticas, marcando sua atuação por meio da guerrilha no campo e dando origem àquilo que chamaremos de primeira fase da nova esquerda. Esta fase duraria até 1968, ano em que ocorreu o golpe militar de Velasco Alvarado.

$\mathrm{Na}$ primeira fase, temos destacadamente a atuação de jovens intelectuais/universitários que abandonaram as cidades e partiram para o campo em busca de organizar movimentos camponeses na luta por terras e o enfrentamento com os gamonales, como ocorreu com Hugo Blanco, em 1962, na região de La Convención, próxima à Cuzco. Mais tarde, esta atuação incorporaria táticas de guerrilha e, em alguns casos, desfrutaria do apoio e financiamento de Cuba no treinamento de militantes na própria ilha, como ocorria com os quadros do MIR. Para Peter Kláren, a vinculação entre o público universitário e a atuação das guerrilhas pode ser assim observada: "quando a população estudantil veio a tona na década de 1960 e as frustrações dos universitários cresceram, o êxito repentino e inesperado da Revolução Cubana, assim como a fragmentação do comunismo internacional, captaram rapidamente sua atenção e sua imaginação. [...] Em 1965, De la Puente e o MIR estabeleceram seu quartel general na planície de Mesa Pelada, na cordilheira oriental dos Andes, perto de Cuzco e não longe de La Convención, unindo-se a eles outros chefes guerrilheiros para planejar a operação conjunta de outros grupos, o Ejército de Liberación Nacional (ELN), fundado por Héctor Bejár e com o vínculos com o PCP, e Túpac Amaru, uma facção do MIR liderado por Guillermo Lobatón. Dois anos antes, o ELN havia enviado um pequeno grupo de jovens intelectuais que 
retornavam de Cuba para que ajudassem a Hugo Blanco em La Convención" (KLAREN, 2005: 356).

Peter Klarén apresenta de maneira clara a vinculação entre as seguidas guerrilhas do período de 1963 a 1965. Também evidencia $\mathrm{o}$ foto de que os dirigentes desses movimentos rebeldes e guerrilheiros, como Luis de la Puente Uceda, Guillermo Lobatón, Héctor Bejár e Hugo Blanco, pertenciam aos setores universitários peruanos. Como vimos em Jorge Nieto, os universitários representaram um núcleo de resistência, uma vez que se viam como intérpretes das reivindicações camponesas à luz do marxismo acadêmico ${ }^{2}$

O fracasso dos movimentos guerrilheiros de 1965, com o MIR e o ELN, e a morte de Che Guevara, em 1967, representaram um duro golpe para a guerrilha enquanto estratégia de tomada de poder no Peru. Além disso, o golpe militar de 03 de outubro de 1968 deflagrado pelo General Velasco Alvarado, levou a nova esquerda a reavaliar a sua posição revolucionária. De certa forma, o governo militar assumiu como bandeira algumas reivindicações que eram próprias da esquerda na década de 1960, como: a reforma agrária e o fim do latifúndio; a distribuição de terras entre as comunidades coletivistas andinas; e o antiimperialismo, representado pela estatização das principais companhias norte-americanas. Assim, a oligarquia e o capital estrangeiro, velhos inimigos da esquerda, passavam a ser combatidos também por outro rival histórico dos movimentos esquerdistas: o Estado.

Tais medidas adotadas pelo Estado fizeram com que boa parte dos guerrilheiros da década de 1960 se aliasse a Velasco e apoiasse as políticas estatais defendendo o real caráter revolucionário do Gobierno Revolucionario de las Fuerzas Armadas (GRFA). Héctor Bejár, um dos membros da esquerda guerrilheira, ao aderir aos projetos de Velasco, compreendeu que o regime militar colocou em marcha um verdadeiro processo revolucionário no Peru, possibilitando que a esquerda ganhasse um protagonismo até então desconhecido. Por conta disso, apoiar Velasco representava uma maneira de continuar trabalhando em prol da revolução no Peru. Essas idéias 
À SOMBRA DE JOSÉ CARLOS MARIÁTEGUI: SOCIALISMO...

aparecem em seu livro Las guerrillas de 1965 e também no artigo mencionado anteriormente.

Para Jorge Nieto, porém, a chegada de Velasco não marcou apenas a adesão da esquerda guerrilheira ao Estado, mas também, o início de um rompimento geracional que resultou na reformulação e revitalização da atuação militante da nova esquerda. Como sugere o autor, o fim das guerrilhas, não representaria, portanto, o fim da nova esquerda, mas uma revisão de suas práticas e o início de uma nova fase.

$\mathrm{Na}$ realidade, a nova geração, auto-proclamada de a geração de $1968^{3}$ em clara alusão a Velasco, ao se afastar das estratégias de guerrilha utilizadas na década de 1960, conseguiu apresentar saídas, como o classismo, para a encruzilhada imposta pelo GRFA que, ao assumir para si "o conjunto de bandeiras e transformações que haviam sido pedidas pela esquerda durante décadas passadas, provoca o esgotamento do pensamento de esquerda do país" (NIETO MONTESINOS, 1990: 388).

Este balanço geracional teria começado ainda na década de 1960. Um exemplo disso seria o folheto organizado por Ricardo Letts, líder estudantil nos anos das guerrilhas e um dos importantes membros da nova geração emergente, intitulado Perú: Revolución, insurrección y guerrillas de 1966. Neste documento, ao fazer um balaço autocrítico das experiências passadas, Letts realiza uma "crítica ao que ele considerava as teorias foquistas da luta guerrilheira; em segundo lugar, desenvolve uma minuciosa análise da operação militar que havia atacado o que apareciam como pontos fracos da estratégia guerrilheira do MIR; e, finalmente, critica o conjunto de ações guerrilheiras dessa época para valorizar o animo revolucionário das massas" (NIETO MONTESINOS, 1990: 387-388).

A partir de então, a nova geração de jovens universitários e intelectuais oriundos da universidade, passaria a defender que o verdadeiro caminho para a revolução não estava no apoio ao Estado, como advertiu Bejár, mas na formação de uma consciência de classe entre as massas de trabalhadores e camponeses. Como escreveu Eduardo Cárceres (Cf. CÁCERES, 
1993), o governo militar foi interpretado por esses jovens como reformista, capaz de produzir tão somente uma caricatura de revolução e, por conta disso, era necessário uma atuação que se desenvolvesse independentemente dessas políticas estatais. Tinha início, dessa maneira, a segunda fase da nova esquerda que perduraria até o final da década de 1970 e a convocação da assembléia constituinte.

Para Nieto, o texto que melhor representa a reorganização estratégica da nova esquerda foi o artigo de Edmundo Murrugarra, Las Tareas Actuales del Proletariado y la Izquierda Marxista-Leninista (A Propósito de la Aparición del Frente de Apoyo y Solidaridad Obrero-Campesino-Intelectual), publicado na revista Crítica marxista-leninista n. 04 em 1972. Entre as diversas críticas apresentadas à ação da esquerda, Murrugarra, propõe quatro novas orientações: "a) a ordem de ir às massas, e em particular a de impulsionar o desenvolvimento do classismo nos associações operários; b) produzir o que ele chama de inversão teórica e desenvolver então pesquisas sociais a partir do marxismo-leninismo; c) a necessidade de aproveitar os espaços abertos pelo processo velasquista e desenvolver a luta de massas, mostrando as limitações desse processo; e d) a necessidade de afirmar, nesse desmascaramento, a ideologia marxista-leninista" (NIETO MONTESINOS, 1990: 390).

Ainda que considere a formulação de novas estratégias de atuação política, Nieto observa que, no campo ideológico, existiram poucas alterações, uma vez que a nova geração aderiu "fielmente" ao marxismo-leninismo. De qualquer maneira, seguindo essas orientações, a nova geração passaria a atuar principalmente junto às barriadas, aos clubes de migrantes, aos movimentos sindicais e as comunidades de bairros naquilo que se denominou classismo. Sendo assim, diferentemente da primeira fase da nova esquerda, que possuiu o campo como seu palco primordial, a geração de 1968 atuou principalmente nas cidades, com destaque para Lima. Desta forma, com o objetivo de desmascarar o processo velasquista, atacou o ponto fraco do GRFA que era a sua incapacidade de mobilização políticopartidária junto às camadas populares, desenvolvida então pelo 
À SOMBRA DE JOSÉ CARLOS MARIÁTEGUI: SOCIALISMO...

SINAMOS, um órgão estatal desenvolvido para atuar como espécie de partido político realizando uma ponte entre o Estado e os movimentos sociais.

Como alternativa ao SINAMOS, realizou um trabalho de conscientização das massas de trabalhadores e migrantes, visando produzir uma consciência de classe e organizar o movimento operário na cidade de Lima. Aos jovens de então, caberia desempenhar uma dupla função, elaborar novas interpretações da realidade social peruana nos bancos das universidades e praticá-las junto aos trabalhadores em busca da preparação de novas lideranças políticas que fossem oriundas do próprio movimento trabalhador ou camponês.

Outra característica desse período foi a aproximação de setores católicos à nova esquerda como resultado de novos questionamentos sobre o papel da Igreja na promoção de justiça social trazidos pela Teologia da Libertação. Por conta disso, a atuação de intelectuais e instituições católicas, como a Pastoral do Andino, junto à nova esquerda, também contribuiu para uma aproximação dos intelectuais aos setores populares.

O resultado desses trabalhos ficou evidente com as greves nacionais, os comícios públicos em bairros operários, as barricadas camponesas interrompendo estradas, as mobilizações estudantis, as marchas de mineiros, entre outras ações que surgiam da colaboração entre estudantes e trabalhadores e serviram como pressão para o governo militar elaborar novas políticas salariais e rever as legislações trabalhistas deste período. Carlos Contreras e Marcos Cueto, afirmam que "o radicalismo nas formas de luta e o desprezo pela 'legalidade' e pela 'democracia parlamentar' caracterizou o movimento [...]. A via da mobilização popular, a insurreição armada, e o não às eleições seriam a maneira de tomar o poder" (CONTRERAS \& CUETO, 2007: 343). Assim se expressou o classismo.

Maruja Martínez, historiadora e militante da geração de 1968, avalia que, para os intelectuais o classismo, configurou-se como "a 'ida ao povo' do final da década de 60 e início da de 70 [... e] acompanhou a reconstituição da CGTP e de muitas de suas 
federações, a expulsão da APRA do sindicato dos bancários, a construção de agremiações sindicais, camponesas, de bairro e juvenis, etc" (MARTÍNEZ, 1991: 119). Estas conquistas serviram para que, finalmente, a esquerda se aproximasse das "multidões".

Neste sentido, a atuação da nova esquerda por meio do classismo produziu um novo público para os partidos de esquerda e ampliou o seu campo de influência. No entanto, paradoxalmente, o trabalho que visava a conscientização das classes para a revolução armada, teve como conseqüência o fortalecimento da opção democrática para o poder.

Em meio à euforia da adesão trabalhadora à nova esquerda, resultante das greves, do trabalho nas barriadas, das marchas camponesas e da intensificação da crise econômica, um setor considerável da nova esquerda optou por participar das eleições para a formação da Assembléia constituinte de 1978. De certa maneira, o resultado das urnas, animou os indecisos a aderir à via democrática. Naquela eleição a nova esquerda, representada por várias alianças pluripartidárias, conseguiu atingir 36\% dos votos, com destaque para a ARI (Alianza Revolucionaria de Izquierda) liderada por Hugo Blanco.

Esta opção, apesar de não marcar o fim do radicalismo na nova esquerda, já que organizações como o MRTA e o Sendero Luminoso, mantiveram-se adeptos da insurreição armada, intensificando suas ações na década seguinte, representou o início da terceira etapa da nova esquerda, marcada pela opção democrática de atuação política. A grande votação recebida por Hugo Blanco na Constituinte de 1978 demonstrava que a esquerda saia de um espaço de marginalidade para atingir seu maior protagonismo na política democrática peruana.

No entanto, os resultados não foram os mesmo nas eleições presidenciais de 1980 e a nova esquerda, dividida ainda em três alianças, perdeu as eleições para Fernando Belaúnde Terry. Ao invés de provocar o desanimo perante à democracia, o resultado promoveu a união entre todos os partidos da nova esquerda em um único movimento: a Izquierda Unida. De certa maneira, a terceira fase da nova esquerda e a formação da IU marcaram o 
encontro das duas gerações que protagonizaram os movimentos esquerdistas das décadas de 1960 e 1970: os guerrilheiros e os classistas. Apareceram lado a lado líderes como Blanco e Javier Diez Canseco, figuras emblemáticas dos movimentos estudantis da década de 1970. A união entre as duas gerações demonstrou que a esquerda da década de 1960 não possuía apenas sutis relações com a esquerda democrática da década de 1980, como defendeu Bejár. Ao nosso ver, os movimentos esquerdistas das décadas de 60 e 80 configuram-se como etapas diferentes de uma mesma "nova esquerda".

Logo em sua primeira disputa, a IU conseguiria eleger Alfonso Barrantes para o importante cargo de prefeito de Lima. No entanto, foi o seu único êxito eleitoral. Em contrapartida, longe das cidades, a ala radical da nova esquerda ampliou a sua influência sobre as regiões serranas do sul peruano. Ao longo da década avançaram sobre o campo, cooptaram camponeses e chegaram às cidades por meio da adesão de andinos nas barriadas. A atuação na zona urbana ficaria marcada por ataques violentos aos prédios públicos e às organizações governamentais. Posteriormente, os ataques se estenderiam aos bairros de classe média alta, como Miraflores e San Isidro e aos seus moradores.

Ao longo da década de 1980, enquanto a esquerda legalista foi perdendo vitalidade e não conseguiu produzir respostas diante da crise que assolava o Peru, a esquerda armada ganhou adeptos e simpatizantes nos movimentos sociais e, até mesmo, em uma pequena parte da esquerda legalista. Por outro lado, a maior parte dos movimentos democráticos de esquerda passou, cada vez mais, a repudiar as ações senderistas, que já naquele momento eram rotuladas de terroristas.

De certa maneira, a oposição acirrada ao Sendero e a falta de opções para um país sem rumo desfigurou a esquerda democrática, realçando suas diferenças pluripartidárias e abrindo espaço para o avanço da direita. Antes mesmo das eleições de 1990, que elegeriam Alberto Fujimori, a IU não existia mais. Enquanto isso, a esquerda armada continuava 
avançando sobre o campo e atacava constantemente a capital federal.

Em síntese, a trajetória que elaboramos da nova esquerda peruana procurou dividi-la em três etapas distintas, marcadas essencialmente pela guerrilha da década de 1960; pelo classismo dos anos 1970; e pela dualidade radicalismo/democracia da década de 1980. No entanto, isso não quer dizer que, no decorrer dessas três décadas a esquerda unida possuiu um pensamento homogêneo. A existência de uma hegemonia com relação a determinada prática de atuação política, como foi a guerrilha ou o classismo, não representou a ausência de contradições ideológicas e práticas dentro da nova esquerda. Ao contrário, as diversas influências do pensamento comunista no plano interno e as várias leituras sobre a realidade peruana dentro da própria esquerda deram origem à um número incontável de partidos e organizações políticas.

Ao longo de sua história, a nova esquerda sofreu inúmeras cisões entre os movimentos que a compuseram. Desde o final da década de 1950 até meados da década de 1980, a crise da esquerda tradicional, os reflexos das revoluções chinesa e cubana e o debate entre as vias democráticas, classista e guerrilheira para a revolução, levariam a dissidências constantes entre os partidos e movimentos políticos que a compunham.

Entre todos o PCP foi o partido com o maior número de ramificações: seis ${ }^{4}$. Apesar de todos terem em comum suas fortes críticas ao PC de Moscou, não conseguiram se unir ao redor de um só líder ou uma única linha ideológica. Por conta disso, essas agremiações possuíram as mais diversas orientações do pensamento comunista daquele momento, como o maoísmo, o guevarismo e o foquismo, o trotskismo e o stalinismo (Cf. KLAREN: 2005).

Além das dissidências do PCP, outros movimentos políticos (de atuação radical, partidária ou classista) ligados à causa revolucionária de orientação chinesa, trotskista ou soviética, surgiram naquele período, como o Partido Proletário del Peru, o Partido Comunista Revolucionário del Perú, o Partido Socialista Revolucionário del Perú, entre tantos. Assim, em 1973, a nova 
À SOMBRA DE JOSÉ CARLOS MARIÁTEGUI: SOCIALISMO...

esquerda estava composta por 53 partidos como ressaltou o historiador Nelson Manrique (MANRIQUE, 2005: 9). Mas, seguramente, atingiu a soma de mais de 60 até o final da década de 1970.

Talvez, o pluripartidarismo que marcou a história da nova esquerda tenha sido um dos responsáveis pelo seu avanço junto às camadas populares, uma vez que abrangia diferentes públicos, de acordo com sua orientação política e ideológica. De qualquer maneira, foi nesse momento em que a esquerda conseguiu apresentar ao grande público o socialismo e o marxismo como um caminho para o Peru, convertendo-se em um dos elementos primordiais para a compreensão da política peruana a partir da década de 1970.

Ainda que no campo ideológico não tenha apresentado muitas novidades, como afirmou Jorge Nieto, a nova esquerda soube construir um espaço de atuação junto às classes trabalhadoras e camponesas que lhe permitiu obter um destaque jamais alcançado pela esquerda tradicional entre 1930 e 1960. De acordo com o comentário do cientista político Alberto Adrianzén, ao artigo de Nieto, “[...] a Nova Esquerda será nova na busca por novos espaços e também, em menor medida, de práticas sociais, porém velha no plano ideológico e com no que se refere ao pensamento político" (ADRIANZÉN, 1990: 26-27).

Por outro lado, essa falta de criatividade no campo ideológico não representou a ausência do pensamento crítico da esquerda seja na adesão às ideologias externas ou nas retomadas de orientações do comunismo e do aprismo primitivos. Queremos dizer que, a filiação ao foquismo, ao maoísmo, ao trotskismo, ao marxismo-leninismo, e outros tantos ismos, não significou a negação das características próprias da realidade peruana e a busca de uma estratégia de construção de um socialismo nitidamente peruano.

De qualquer maneira, é preciso que façamos uma reflexão em torno da apropriação que intelectuais e movimentos políticos fazem de ideologias externas. Esse movimento não se constitui como uma simples tradução ou cópia. A importação de idéias ocorre, pois, de alguma maneira, tais teorias fazem sentido para 
uma determinada localidade. Esta é uma problemática levantada por Gerardo Leibner ao analisar a influência de correntes européias no pensamento de Mariátegui, com a qual concordamos. Segundo Leibner, "as idéias criadas em outra sociedade e em outras circunstâncias não influenciam simplesmente o pensador, mas é ele quem as escolhe na medida em que elas respondem a certas necessidades de sua reflexão" (LEIBNER, 1999: 12).

Olhando dessa maneira, podemos compreender, por exemplo, a reinterpretação do maoísmo para o Peru como uma forma de se estabelecer relações entre a força do camponês no movimento chinês e o papel que este poderia possuir para uma revolução no Peru. O mesmo ocorre com a teoria da Revolução Permanente de Trotsky e sua interpretação de que, em países de capitalismo tardio, a burguesia nasce em conflito com o próprio camponês não elegendo a aristocracia rural como sua única inimiga como ocorreu em outros países detentores de uma burguesia histórica. A interpretação do Peru como um país précapitalista e, até mesmo, feudal era uma realidade no pensamento político daquela época que o aproximava às teorias trotskistas.

Até mesmo a produção acadêmica produzida neste momento de aglutinação universitária e militância partidária, nos permite afirmar a existência de uma preocupação em se compreender elementos peculiares da realidade social peruana. Ainda que tivessem o marxismo como principal método analítico, conseguiram enxergar em personagens tipicamente peruanos, como o andino, os verdadeiros agentes da revolução. A retomada de Mariátegui por todos os membros da nova esquerda após um longo período de esquecimento é um claro intento de se pensar tais influências por meio de um viés peruano.

Não há dúvidas que entre as referências teóricas e práticas que contribuíram para que a Nova Esquerda rompesse com esquemas tradicionais e buscasse novas maneira de se pensar e agir tanto na história quanto na política, José Carlos Mariátegui é a principal. Em um momento de crise de paradigmas e de 
À SOMBRA DE JOSÉ CARLOS MARIÁTEGUI: SOCIALISMO...

decadência da esquerda tradicional, o marxismo singular de Mariátegui se apresentou como uma maneira de se forjar um marxismo legitimamente peruano. $\mathrm{E}$ qual era o marxismo singular de José Carlos Mariátegui?

Aqui encontramos um problema. As leituras realizadas sobre o pensamento de Mariátegui produziram um número inesgotável de interpretações do que haveria sido o marxismo do autor. As interpretações de Mariátegui, que aqui chamaremos de mariateguismo, não são um fenômeno homogêneo. Ao lermos as obras que procuram dar conta de decifrar o pensamento do socialista, podemos encontrá-lo relacionado às mais diversas filiações literárias, políticas e ideológicas: romântico, revolucionário, reformista, populista, indigenista, modernista, entre outros. Como observa Alberto Aggio, temos "em relação a suas idéias, um conjunto de interpretações, às vezes desencontradas e até mesmo antagônicas, que se confrontam num verdadeiro campo de batalha cujo resultado, na maioria das vezes, tem sido o de despedaçar o seu pensamento" (AGGIO, 2005: 108).

Ao invés de possibilitarem o esclarecimento do pensamento de Mariátegui, tais obras produzem incertezas e contradições ao ponto de não podermos afirmar, enfim, o que foi realmente pensado por ele. Por outro lado, algumas dessas interpretações foram assumidas por partidos e movimentos políticos como as "verdadeiras" heranças deixadas por Mariátegui, não admitindo críticas ou a revisão de seu pensamento. Podemos dizer que Mariátegui, a partir da década de 1960, foi se transformado em uma espécie de mito e, por conta disso, sua abordagem é extremamente delicada, uma vez que ao discutirmos aspectos de sua obra podemos atacar certas paixões consolidadas que não seriam discutidas academicamente, mas a partir de dogmas prévios.

Ao mesmo tempo em que se produz essa multiplicação de correntes explicativas e ideológicas, e talvez por decorrência disso, podemos verificar a popularização de Mariátegui enquanto personagem histórico. Mariátegui é sem dúvida um fenômeno que transpassa a cultura política peruana e compõe 
seguramente o arcabouço de referências da cultura peruana como um todo. Nas ruas, nos taxis, nas bancas de jornais, nos cafés, nas livrarias especializadas e não especializadas, Mariátegui é uma figura facilmente identificada tanto pelo cidadão comum ou pelo intelectual especializado no assunto.

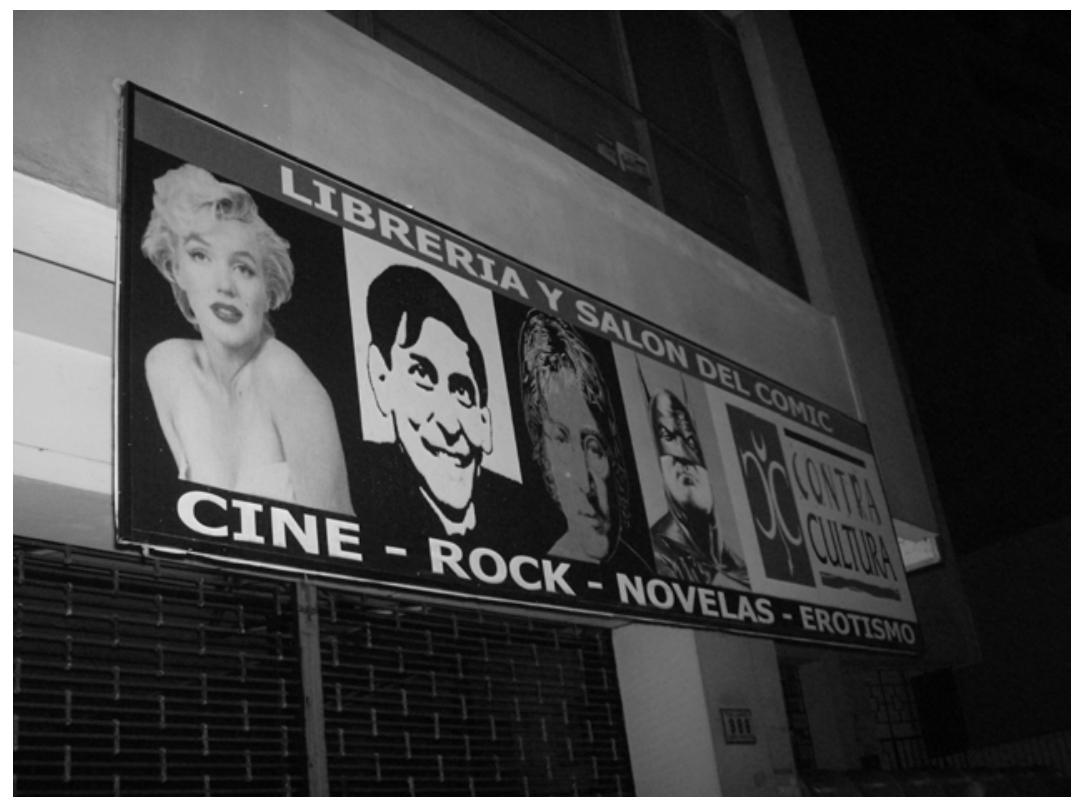

FIGURA 1: Fachada da Livraria Contra Cultura localizada na Av. José Larco n. 986 - Miraflores - Lima Peru - Jul./2007). A figura de Mariátegui encontra-se disposta juntamente com outros ícones da cultura pop ocidental do século XX.

FONTE: Arquivo Pessoal. 
Não temos dúvida de que a explicação para este fenômeno se encontra localizada na década de 1970, como reflexo do "revival mariateguiano no Peru [...]" (ARICÓ, 1978: XI), observado pelo argentino José Aricó. Esta percepção se reforça ao olharmos para a história de Mariátegui e do mariategismo. Após a sua morte em 1930, suas obras e idéias caíram em certo esquecimento: o Partido Comunista Peruano deu início a uma campanha de desmariateguização de suas diretrizes; a Internacional Comunista o acusou de populista; e uma série de ataques, relacionando a sua condição física à estrutura de seu pensamento, partiu de seus antigos adversários políticos, os apristas. Portanto, somente após a metade da década de 1960 foi que a figura de Mariátegui atingiu um prestígio que nem mesmo em vida possuiu.

Entre 1914 e 1930, datas que marcam a distância entre o seu primeiro e último artigo, Mariátegui produziu uma série quase que incontável de textos, artigos, cartas e livros. Tinha como característica a produção de artigos para jornais e revistas e, após muito discorrer sobre um tema, organizá-los em pequenos livros. Em seus textos, apresentou a necessidade de se produzir um marxismo puramente peruano e um caminho para o socialismo que respeitasse as tradições nacionais. Morreu sem estabelecer um projeto para tanto.

Podemos dizer que a morte de Mariátegui sem produzir um modelo acabado de teoria socialista, deu margem ao início da história do mariateguismo. Como observa José Aricó, em seu livro Mariátegui y los origines del marxismo latino americano de, 1978, “apenas morto Mariátegui é que se desata entre os intelectuais e militantes políticos peruanos uma aguda polêmica em torno da definição ideológica e política de suas idéias" (ARICÓ, 1978: XXIII).

A primeira atitude tomada pela Internacional Comunista, por exemplo, foi a de sepultar o pensamento de Mariátegui junto com o seu autor. Seguindo determinações da esquerda soviética, Eudócio Ravines, substituto de Mariátegui como dirigente do Partido Socialista Peruano, alterou o nome do partido. Concomitante a isso, teve início um processo de combate ao 
"mariateguismo" e ao "amautismo" 5 . Era preciso afastar a heterodoxia e a presença da intelectualidade e da pequena burguesia, características cultivadas pelo partido na época de Mariátegui.

Não demoraria para que a intelectualidade do Partido Comunista produzisse seus ataques ao peruano. Passado alguns anos de sua morte, em 1941, apareceu um artigo do russo Mirochevski, importante personalidade comunista, intitulado El populismo en el Perú ${ }^{6}$. Como sugere o título, Mariátegui é alçado à condição de populista, o que, "nas décadas de 1930 e 1940 [...] depois de trotskista era, sem dúvida, a acusação mais infame" (ARICÓ, 1978: XXXVI), como alertou Aricó.

Ocorre que, dois anos mais tarde, como reflexo do reordenamento da política peruana e do posicionamento russo durante a segunda guerra mundial, a interpretação da estratégia de classe contra classe começou a perder força dentro do Partido Comunista Peruano, o que culminou com a expulsão de Ravines, em 1944. Por conta disso, a figura de Mariátegui voltou a ser relacionada às origens do partido. Assim, em 1943, Jorge del Prado, Secretário Nacional de Organização do PCP publicaria um texto intitulado Mariátegui, marxista-leninista fundador del Partido Comunista Peruano: primer divulgador y aplicador del marxismo en el Perú (DEL PRADO, 1978: 71-92). Porém, ao contrário daquele Mariátegui que se combatia após a sua morte, este Mariátegui "ressuscitado" por del Prado era um convicto defensor do marxismo-leninismo, seguidor fiel do stalinismo e militante da causa bolchevique. Como continuidade desta retomada, no ano seguinte, sob a tutela do PCP, seria publicada a segunda versão dos Sete ensaios, dezesseis anos após sua aparição. Este seria apenas o primeiro capítulo do retorno ao pensamento de Mariátegui, um processo que ainda hoje não atingiu seu fim.

À partir de meados da década de 1950 e principalmente na década de 1960, a crise do comunismo tradicional provocada pelo embate chino-soviético e a revolução cubana produziram uma interpretação de que era possível constituir um caminho próprio para o socialismo em cada localidade. Pensar um 
socialismo/marxismo próprio para o Peru significava retomar os embates travados por Haya e Mariátegui (1927) e Mariátegui e a Internacional Comunista (1928), ainda na década de 1920.

Por conta disso, para os novos partidos que surgiram daquele momento de fragmentação da esquerda tradicional, Mariátegui representava uma figura muito emblemática. Ao mesmo tempo em que se caracterizava como o intento de se produzir um comunismo tipicamente peruano, simbolizava o rechaço ao comunismo soviético e ao aprismo. Mariátegui passava a ser, portanto, a representação de um caminho para a revolução independente da URSS (PCP) ou da APRA.

$O$ fenômeno do mariateguismo atingiria o seu auge, sem dúvida na década de 1970, com a produção do revival mencionado por Aricó. Na realidade, o posicionamento da nova esquerda como tributária do pensamento de Mariátegui se replicou em todos os seus partidos e, à medida que avançou a década de 1970 e as cisões partidárias se ampliaram, outros Mariáteguis surgiram. Como no alcorão ou na bíblia, cada trecho da obra de Mariátegui passou a ser interpretado de uma maneira a dar sentido e legitimidade à ação de cada partido político ${ }^{7}$.

Uma forma de percebermos o aumento do interesse pelo pensamento de Marátegui, na década de 1970, é por meio do acompanhamento do número de publicações de sua principal obra. A primeira edição dos Sete Ensaios é de 1928. A segunda apareceu somente em 1944. Entre 1928 e 1959 foram apenas seis edições desta obra. Já em 1963, foram produzidas apenas três novas edições. No entanto, das 60 edições publicadas entre 1928 e 1994, metade foi produzida entre de 1968 e 1980. Só em 1969, por exemplo, sairiam quatro novas publicações. Esta retomada de Mariátegui também seria acompanhada pela elaboração de trabalhos sobre sua obra por autores não peruanos, como o italiano Antonio Melis, o argentino José Aricó e o francês Robert Paris, além da publicação do Sete ensaios na Itália, México, Brasil e Estados Unidos.

De certa forma, a chegada de Velasco Alvarado ao poder, também contribuiu para a intensificação desse processo. $O$ GRFA era composto por oficiais formados no CAEM ao longo das 
décadas de 1950 e 1960 que, além de possuírem proximidade com algumas linhas do pensamento marxista, também eram anti-apristas. Assim, o reconhecimento da importância de Mariátegui como um dos principais intelectuais peruanos também reforçava o seu repúdio ao líder histórico da APRA (Victor Raúl Haya de la Torre).

Evidentemente que o Mariátegui de Velasco não poderia ser o mesmo daquele defendido pelo classismo e da geração intelectual de 1968. Por conta de sua atuação junto às centrais trabalhistas, esta característica do socialista seria também ressaltada. A idéia de que o partido seria o resultado de um amadurecimento da classe operária, por exemplo, era reforçada por um trecho de um artigo de Mariátegui sobre o primeiro de Maio de 1924, no qual dizia que os partidos políticos no Peru eram muito jovens para se configurar como força política (MARIÁTEGUI, 1924). A própria revitalização da CGTP (Central General de Trabajadores del Perú) na década de 1970, também representou essa intenção.

Assim, a atuação de Mariátegui junto às massas, como organizador dos movimentos de trabalhadores e sindicatos, professor das universidades populares González Prada, editor de revistas voltadas para o operariado, como Labor, reforçava nesses atores a perspectiva de que o classismo era um caminho mariateguista de promoção da revolução.

Ainda para a geração de 1968, em sua vertente acadêmica mais radical, a Nova História, Mariátegui também se concretizou como um referencial. O socialismo mariateguista passou a ser analisado historiograficamente para que, a partir daí, pudesse alimentar a construção de uma nova imagem histórica do país. Como nos lembra Paulo Drinot, os membros da Nova História peruana "encontraram no trabalho de José Carlos Mariátegui, uma teoria explicativa nacional e original para a história e sociedade peruana" (DRINOT, 2003: 57).

De outra maneira, Mariátegui representava a opção por um tipo de intelectual que congregava a elaboração teórica com a militância revolucionária. Ainda como reflexo desta conjugação de militância com a atuação de historiadores/professores, 
Mariátegui passou a freqüentar livros escolares e atingiu as salas de aulas, contribuindo para a sua popularização.

Assim como para o classismo, Mariátegui foi referência para justificar as mais diversas práticas e estratégias políticas, inclusive a via armada senderista. O nome do Sendero Luminoso deriva do lema do Partido que dizia: Partido Comunista Peruano por el sendero luminoso de José Carlos Mariátegui. Ainda que reconstruído à imagem e semelhança de cada partido que o adotava, Mariátegui foi o "patriarca" de todos os movimentos da nova esquerda no Peru. Justamente por isso, quando a esquerda se uniu em torno de um único bloco para a disputa de eleições, na década de 1980, seu símbolo não poderia ser outro senão o autor dos Sete ensaios. Paradoxalmente, Mariátegui era um traço que os aproximava e, ao mesmo tempo, os separava. Além da vontade de se atingir o poder, esta imagem era o único traço que os inúmeros partidos tinham em comum. No entanto, esta comunhão era muito mais simbólica do que ideológica, uma vez que a interpretação em torno do socialismo de Mariátegui era um ponto de discordância entre eles.

A imagem caleidoscópica de José Mariátegui no início da década de 1980 era algo tão marcante que o historiador Alberto Flores Galindo chegou a afirmar que Mariátegui, contra sua própria vontade, havia se convertido em empecilho para o avanço da esquerda. Como escreveu em um artigo, Socialismo y problema nacional, de abril de 1980, "existe uma imagem mitificada de José Carlos Mariátegui que o apresenta como o marxista ortodoxo por excelência, o guia da revolução socialista, o caminho iluminado, o Amauta [...]. A veneração bíblica substitui a discussão. Desta maneira, e para o seu pesar, Mariátegui acaba por se converter em um obstáculo para o desenvolvimento do marxismo no Peru. [...] Se faz necessária a tarefa pouco grata de desmistificar a Mariátegui. O caminho consiste em trazê-lo novamente para a história, restituí-lo àquilo que ele realmente foi, um homem de seu tempo, e pensá-lo, segundo uma bela reflexão de Sartre, que dizia: "como todo homem é feito de todos os homens e que vale como todos e quaisquer uns deles". Em outras palavras, trata-se de intervir 
em algumas perspectivas que estudam a Mariátegui como se ele tivesse existido sozinho, desligando-o de seu contexto ou enfrentando-o com outros solitários" (FLORES GALINDO, 1988: $46)^{8}$.

As múltiplas imagens de Mariátegui foram recentemente retratadas pelo autor peruano David Sobrevilla em seu livro El marxismo de Mariátegui y su aplicación a los 7 ensayos, de 2005. Este livro ainda que tenha como objetivo central a análise do marxismo de Mariátegui nos Sete ensaios, apresenta um capítulo exclusivo cujo intuito é mapear os diversos autores, obras e correntes que reinterpretaram o pensamento mariateguiano.

Este mapeamento nos permite mensurar o quanto o pensamento do socialista serviu aos mais variados gostos, desde 1943 até o início do século XXI. No entanto, o exercício de Sobrevilla se torna inovador à medida que o autor classifica e divide as diversas interpretações de Mariátegui em três blocos dispostos da seguinte maneira: Mariátegui enquanto um não marxista; Mariátegui enquanto um marxista ortodoxo; e Mariátegui enquanto um marxista heterodoxo.

O primeiro bloco resulta no mínimo curioso, uma vez que apresenta alguns autores que, ao analisarem o pensamento de Mariátegui, chegaram à conclusão de que o "marxista convicto e confesso", não era marxista. Entre essas interpretações o autor destaca os "Mariáteguis": populista, contraditório, aprista, filósofo da ação, espiritualista e anti-marxista.

O segundo bloco é formado por autores que identificaram em Mariátegui uma filiação à "doutrina oficial soviética tal como foi anunciada por Stalin em seu texto de 1938 'Sobre o materialismo dialético e o materialismo histórico', no Breve curso da história do PC da União Soviética" (SOBREVILLA, 2005: 4647). Neste momento, Sobrevilla analisa as obras de Jorge del Prado, Moisés Arroyo Posadas, Raimundo Prado Redondez, Narciso Bassols Batalla e Harry E. Vanden.

Aqui destacamos as análises feitas pelo autor às obras de Jorge del Prado, que não é apenas o iniciador dessa corrente mariateguista ortodoxa, como também, se considera um revisor dessa leitura. Para del Prado, em um primeiro momento (1943), 
Mariátegui se aproximaria de Lenin e Stalin. Posteriormente, na década de 1980 (1984), o mesmo autor o distancia de Stalin, mas o aproxima de Marx e Lenin. Nesta virada de posição, não deixaria de sobrar espaço para atacar aqueles por ele considerados como tergiversadores do pensamento mariateguista (Luis Alberto Sánchez, Eugenio Chang-Rodríguez e Hugo García Salvatecci) e os revisionistas (José Aricó e Alberto Flores Galindo).

O terceiro bloco de autores é composto por obras que identificam Mariátegui como representante de "[...] correntes do marxismo que não seguem a filosofia oficial soviética, ou seja, a doutrina do materialismo dialético. Neste caso se fala também de neomarxismo" (SOBREVILLA, 2005: 55). Essas interpretações apresentam o pensamento de Mariátegui como: um marxismo aberto (Augusto Salazar Bondy), um outro marxismo (Antonio Melis), um marxismo soreliano (Robert Paris), um marxismo como um método de interpretação (Diego Meseguer), um marxismo indoamericano e um marxismo como busca de uma racionalidade alternativa (Aníbal Quijano); e mais: um marxista lukacsiano (José Ignácio López Soria), um marxismo romântico (Michel Lowy), um marxismo herético (Raúl Fronet-Betancourt) e um marxismo como versão latino-americana da filosofia da práxis de Antonio Labriola (Jorge Oshiro).

Ao final deste capítulo, Sobrevilla, realiza suas próprias considerações sobre Mariátegui e demonstra a sua filiação à heterodoxia, aproximando-se das interpretações de Melis e Meseguer, uma vez que "ambas partem de um sólido trabalho textual, sem preconceitos e sem interesses, que busca reconstruir o pensamento de Mariátegui a partir do que escreveu. Nos dois casos rastreiam as influências operantes sobre o Amauta, porém reconhecendo que ele as assume de forma criadora" (SOBREVILLA, 2005: 84).

De certa forma, o trabalho de José Aricó anteriormente mencionado, já havia alertado para a existência dessa multiplicidade de interpretações do pensamento de Mariátegui. No livro, o autor apresenta uma coletânea de artigos confeccionados, em diversas épocas, por diferentes interpretes 
de várias filiações ideológicas sobre o peruano. Entre as interpretações se destacam aquelas que viram Mariátegui como um aprista, um populista, um soreliano e um marxista-leninista.

A intenção de Aricó com a organização do livro era confrontar as diversas visões e realizar uma aproximação à leitura dos textos originais de Mariátegui. Como anunciou, "admitindo como um suposto irrecusável a "criticidade" do marxismo, nossa recopilação se propôs incluir um conjunto de textos cujas controvertidas posições remeteram ao caráter crítico do marxismo de Mariátegui. Sua leitura cuidadosa nos ajuda a compreender as falácias que conduzem as tentativas de definir o pensamento de Mariátegui em termos de "adoção" ou encontro com determinadas correntes ideológicas. Se resultam falidas as tentativas de convertê-lo em um marxista-leninista (e, por que não, stalinista?) cabal; aparecem como arbitrárias as qualificações de "aprista de esquerda", "populista"ou "soreliano" [...] (ARICÓ, 1978: XIII-XIV).

O diferencial da obra de Aricó está no fato de ter sido publicada ainda em 1978, portanto, no auge da explosão do mariateguismo. Apresenta-se, por isso, como um dos primeiros intentos de racionalizar historicamente $o$ personagem $e$ questionar os dogmatismos que o cercavam e, ao mesmo tempo, anunciá-lo como algo realmente novo e não somente uma cópia ou tradução de outras ideologias.

Por outro lado, a obra de Sobrevilla, datada de 2005 nos deixa claro o quanto a figura de Mariátegui ainda se constitui como um ponto de partida e referência maior para se pensar os caminhos das esquerdas peruanas e latino-americanas até os dias de hoje. De certa forma, o mariateguismo construído ao longo das décadas de 1960 e 1970 se expandiu para além dos marcos ideológicos da cultura política peruana e passou a influenciar também políticos de correntes centristas ou direitistas. Mariátegui e suas diversas imagens continuam a pairar como uma sombra sobre as orientações da esquerda e dos movimentos políticos no século XXI. 
À SOMBRA DE JOSÉ CARLOS MARIÁTEGUI: SOCIALISMO...

\section{Referências Bibliográficas}

ADRIANZÉN, Alberto. (Ed.).Pensamiento político peruano: 1930 - 1968. Lima: Desco - Centro de Estudios y Promoción del Desarrollo, 1990.

AGGIO, Alberto. O pensamento político de Mariátegui. In: Política Democrática. Revista de Política e Cultura. $\mathrm{N}^{\circ} 12$, ano V, Brasília: Fundação Astrojildo Pereira, 2005.

ARICÓ, José. Mariátegui y los orígenes del marxismo latinoamericano. México: Ediciones Pasado y Presente, 1978.

BEJÁR, Héctor. Los Orígenes de la nueva izquierda en el Perú: la izquierda guerrillera (período 1956-1967). In: ADRIANZÉN, Alberto. (Ed.).Pensamiento político peruano: 1930 - 1968. Lima: Desco - Centro de Estudios y Promoción del Desarrollo, 1990.

CONTRERAS, Carlos; CUETO, Marcos. Historia del Perú contemporáneo. 4. ed. Lima: IEP, 2007.

FLORES GALINDO, Alberto. La agonía de Mariátegui. La polémica con la Komitern. Lima: DESCO, 1980.

. Socialismo y Problema Nacional en el Perú.

In: . Tiempo de Plagas. Lima: Caballo Rojo, 1988.

KLAREN, Peter. Nación y Sociedad en La Historia del Perú. Lima: IEP, 2005

MARIÁTEGUI, José Carlos. El primero de mayo ya el frente único. In: El Obrero Textíl, vol. V, No. 59, Lima, 1924.

Editora Amauta, 1994.

. Mariátegui Total. Tomo I. Lima: Empresa

MARTÍNEZ, Maruja. Una vez más, sobre la generación del 68. In: Márgenes: encuentros y debates . Ano IV, n. 7. Lima: SUR, 1991, p. 119.

MURRUGARRA, Edmundo. Las Tareas Actuales del Proletariado y la Izquierda Marxista-Leninista (A Propósito de la Aparición del Frente de Apoyo y Solidaridad Obrero-Campesino-Intelectual). In: Crítica marxista-leninista. n. 04, 1972.

NIETO MONTESINOS, Jorge. ¿Vieja o Nueva Izquierda? In: ADRIANZÉN, Alberto. (Ed.).Pensamiento político peruano: 1930 - 1968. Lima: Desco - Centro de Estudios y Promoción del Desarrollo, 1990.

PARIS, Robert. La formación ideológica de José Carlos Mariátegui. México: Ediciones Pasado y Presente, 1981. 
SOBREVILLA, David. El marxismo de Mariátegui y su aplicación a los 7 ensayos. Lima: Fondo de Desarrollo Editorial/Universidad de Lima, 2005.

PINHEIRO, Marcos Sorrilha. Under the Shadow of José Carlos Mariátegui: socialism and leftist political movements in Peru (1960-1980). História, v.28, n.2, p.837-866, 2009.

\begin{abstract}
The Peruvian intellectual José Carlos Mariátegui is one of the most important political-ideological references of LatinAmerican socialism in the 20th century and creator of a new kind of socialism to continent. However, during the 1930s to 1950 the name of Mariátegui wasn't a significant name for the Peruvian left. Only in the 1960 decade was that the Siete Ensayos author's name renumbered as inheritance claimed by political parties and movements that formed the New Left Peru. In this article we will present how the ideas of Mariátegui have been included for these movements within a context of redrafting of the left in the Latin American and world. In a first moment we'll presents the emergence and consolidation trajectory of the new left Peru and its main lines of action. We then producing exactly review of the role that the ideas of Mariátegui played for intellectuals and Peruvians parties linked to these entries.
\end{abstract}

Keywords: Peruvian New Left; José Carlos Mariátegui; Socialism.

\title{
NOTAS
}

${ }^{1}$ El Antiimperialismo y el Apra é uma obra de Víctor Raúl Haya de la Torre publicada em Santiago, Chile, pela editora Ercilla em 1936. Nela aparecem os principais objetivos do aprismo e a sua estratégia de atuação política que serviria de guia para os militantes até meados da década de 1940.

${ }^{2}$ De certa forma a origem universitária seria uma característica da nova esquerda em todos os seus períodos. O próprio Sendero Luminoso, que 
À SOMBRA DE JOSÉ CARLOS MARIÁTEGUI: SOCIALISMO...

se desenvolveu ao longo da década de 1970 e apareceu com força na década de 1980, era liderado por Abimael Guzmán, um professor universitário de filosofia.

${ }^{3}$ Além do GRFA, esta geração também se chamou de 1968 por conta da influência do maio francês e a importância dada à juventude naquele "movimento político-cultural".

${ }^{4}$ Em 1978, por exemplo, os partidos comunistas originados do PCP eram: o PCP-ER (Estrella Roja), o PCP-SL (Sendero Luminoso), o PCP-PR (Patria Roja), o PCP-ML (Marxista Leninista), o PCP-BR (Bandera Roja) e o PCP-U (Partido Comunista Peruano de la Unión). Somado a esses, não podemos nos esquecer do ELN já citado.

${ }^{5}$ No caso do aprismo, a primeira atitude foi de ataque a figura de Mariátegui como um intelectual contraditório, conforme aparece no artigo de Manuel Seoane Contraluces de Mariátegui de 1930. À partir de 1934, com o artigo Reflexiones sobre José Carlos Mariátegui de Carlos Manuel Cox, o aprismo iniciou uma aproximação a Mariátegui afirmando as afinidades entre ele e Víctor Raúl Haya de la Torre. Em 1957, o também aprista Eugenio Chang-Rodriguez, seguindo a estratégia de Cox, publicou um livro intitulado La literatura política de González Prada, Mariátegui y Haya de la Torre na qual defende que, Mariátegui, na realidade, nunca fora um marxista. (Cf. SOBREVILLA, 2005: 40-41).

6 Ver: MIROSHEVSKI, V. M. El "Populismo" en el Perú. Papel de Mariátegui en la historia del pensamiento social latino-americano. In: (ARICÓ, 1978: 55-70). Deve-se atentar para o fato que o vocábulo "populista" aqui não tem o mesmo significado que se tronou generalizado nas ciências sociais latino-americanas e sim, o significado de uma aproximação ao que se entendia comparativamente ao populismo russo.

${ }^{7}$ Apenas alguns exemplos: O Sendero Luminoso de 1980 recebeu este nome em referência a José Carlos Mariátegui. No início da década de 1980 Javier Diez Canseco fundou o PUM Partido Mariateguista Unificado. Em 1967 a editora oficial do partido Pátria Roja realizou a organização de um livro com uma série de textos de Mariátegui. O Sutep, sindicato dos profissionais da educação, utiliza, até os dias de hoje, a imagem do rosto de Mariátegui em suas bandeiras. Os informativos oficiais da Esquerda unida, partido que conglomerou todos os partidos de esquerda da nova esquerda, menos o MRTA e o 
Sendero Luminoso, traziam como emblema da aliança uma imagem estilizada de Mariátegui.

${ }^{8} \mathrm{O}$ artigo foi publicado originalmente em: Nueva Sociedad, n. 47 de abril de 1980.

Artigo recebido em 08/2009. Aprovado em 11/2009. 